\title{
UNIVERSITYOF
}

FORWARD

THINKING

WESTMINSTER用

WestminsterResearch

http://www.westminster.ac.uk/westminsterresearch

\section{The Standing of Indirectly Injured States in the Litigation of Community Interests before the ICJ: Lessons Learned and Future Implications in Light of The Gambia v. Myanmar and Beyond Longobardo, $M$.}

This is the peer reviewed version of the following article: Longobardo, M. 2021. The Standing of Indirectly Injured States in the Litigation of Community Interests before the ICJ: Lessons Learned and Future Implications in Light of The Gambia v. Myanmar and Beyond. International Community Law Review. 23. Advanced online publication. DOI: 10.1163/18719732-12341480, which has been published in final form at:

https://doi.org/10.1163/18719732-12341480.

The WestminsterResearch online digital archive at the University of Westminster aims to make the research output of the University available to a wider audience. Copyright and Moral Rights remain with the authors and/or copyright owners. 


\title{
The Standing of Indirectly Injured States in the Litigation of Community Interests before the ICJ: Lessons Learned and Future Implications in Light of The Gambia v. Myanmar and Beyond
}

\author{
Dr Marco Longobardo*
}

\begin{abstract}
This article explores the legal challenges related to the standing of indirectly injured states before the International Court of Justice in relation to violations of obligations erga omnes and erga omnes partes. After an examination of the emergence of these kinds of obligations, the article addresses the evolution of the approach of the Court in relation to the issue of standing, in light of the works of the International Law Commission on state responsibility. Especially after the 2012 Belgium v. Senegal case, the Court does not hesitate to recognise the standing of indirectly injured states. Yet, some aspects related to standing - such as the requirement of a special interests and the coordination between the reaction of the directly injured state and the indirectly injured ones - are still imprecise. The Court should take the opportunity to elaborate on these issues in the merits phase of The Gambia v. Myanmar case.
\end{abstract}

Keywords: genocide; International Court of Justice; obligations erga omnes; obligations erga omnes partes; standing

\footnotetext{
* Lecturer in International Law, University of Westminster, m.longobardo1@westminster.ac.uk. This article expands some ideas I have presented in a number of research events over 2020 at the University of Westminster (18 February 2020), the University of Messina (24 February 2020), the British Institute of International and Comparative Law, London (24 June 2020), and the City University of London (17 November 2020). I thank the organisers (especially, Irene Pietropaoli, Jed Odermatt, and Mauro Barelli) and participants of those events for the feedback I have received. Thanks also to Marcella Distefano and Malgosia Fitzmaurice for some comments on a previous draft. All the websites were last accessed on 9 December 2020, when this article was finalised.
} 
Better to give States standing in Court to protect what they perceive as global values than to leave them only with non-judicial means of dispute settlement, whether in the guise of countermeasures or under the rubric of 'responsibility to protect'. ${ }^{1}$

\section{Introduction}

This article explores some of the legal challenges facing states that want to litigate community interests before the International Court of Justice (ICJ). Community interests hereby refers to "a consensus according to which respect for certain fundamental values is not to be left to the free disposition of states individually or inter se but is recognized and sanctioned by international law as a matter of concern to all states"2 or to some states that are parties to the same treaties. These rules are usually referred to as obligations erga omnes and erga omnes partes. The legal challenges analysed here pertain to the litigations of violations of these rules by those states which are not directly affected by a violation of a rule of international law owed towards them or towards a group of states, but rather, that nonetheless have a legal interest in other states' compliance with that rule. Contrary to the terminology employed by the United Nations (UN) International Law Commission (ILC) and following significant scholarship, ${ }^{3}$ these states are referred here as 'indirectly injured' or 'not directly injured' states rather than 'non-injured states' because every state in the international community or every state party to certain treaties is injured as a result of violations of these kinds of obligations. ${ }^{4}$

\footnotetext{
1 James Crawford, "Responsibility for Breaches of Communitarian Normas: An Appraisal of Article 48 of the ILC Articles on Responsibility of States for International Wrongful Acts" in U. Fastenrath et al (eds), From Bilateralism to Community Interest: Essays in Honour of Bruno Simma (2011) p. 225.

2 Bruno Simma, "From Bilateralism to Community Interest in International Law", 250 Recueil des Cours (1994) p. 233.

${ }^{3}$ See, e.g., Theodor Meron, "International Law in the Age of Human Rights: General Course on Public International Law", 301 Recueil des Cours (2004) p. 278; Jean-Marc Thouvenin, "La saisine de la Cour internationale de Justice en cas de violation des règles fondamentales de l'ordre juridique international", in C. Tomuschat and J.-M. Thouvenin (eds), The Fundamental Rules of the International Legal Order: Jus Cogens and Obligations Erga Omnes (2006) p. 327.

${ }^{4}$ See, e.g., Kyojy Kawasaki, "The 'Injured State' in the International Law of State Responsibility", 28 Hitotsubashi Journal of Law and Politics (2000) p. 22; Brigitte Stern, "Et si on utilisait la notion de préjudice juridique? Retour sur une notion délaissée à l'occasion de la fin des travaux de la C.D.I sur la responsabilité des États", 47 Annuaire Français de Droit International (2001) pp. 23-24; Pierre-Marie Dupuy, "A General Stocktaking of the Connections between the Multilateral Dimension of Obligations and Codification of the
} 
The decision to write this article is occasioned by some recent events that offer an opportunity to assess current trends pertaining to the litigation of community interests. In particular, in 2019 The Gambia launched a case against the Myanmar for alleged violations of the ban on genocide, which led to an order on provisional measures in January 2020 (The Gambia v. Myanmar case). ${ }^{5}$ This case involves community interests from multiple perspectives: not only is The Gambia not an injured state in the traditional sense, but also the dispute attracted the attention of other states, such as the Maldives, Canada, and the Netherlands, who announced the intention to intervene. ${ }^{6}$ Moreover, in September 2020, the Netherlands announced the decision to take action against Syria for alleged violations of the ban on torture, which may end before the ICJ. ${ }^{7}$ In light of these events, a rigorous analysis of the legitimation of these states to litigate community interests is particularly timely.

The article opens with a cursory overview of the emergence of community interests in international law and their irruption in the case law of the ICJ and in the ILC's works on the codification of state responsibility. The article goes on to track the developments in the ICJ's approaches to claims regarding community interests that were brought by indirectly injured states, noting an increased trend of the ICJ in recognising the standing of those states. Finally, the article assesses the successes and pitfalls of the case law of the ICJ in relation to the litigation of community interests, trying to demonstrate the huge potentiality of this kind of litigation in an array of areas of international law.

\footnotetext{
Law of Responsibility", 13 European Journal of International Law (2002) pp. 1073-1074; Yoshifumi Tanaka, The Peaceful Settlement of International Disputes (2018) p. 321.

${ }^{5}$ Application of the Convention on the Prevention and Punishment of the Crime of Genocide (The Gambia v. Myanmar), Order of 23 January 2020.

6 "The Republic of Maldives to file declaration of intervention in support of the Rohingya people, at the International Court of Justice", 25 February 2020, https://foreign.gov.mv/index.php/en/mediacentre/news/5483-the-republic-of-maldives-to-filedeclaration-of-intervention-in-support-of-the-rohingya-people,-at-the-international-court-of-justice; “Joint statement of Canada and the Kingdom of the Netherlands regarding intention to intervene in The Gambia v. Myanmar case at the International Court of Justice", 02 September 2020, https://www.government.n//documents/diplomatic-statements/2020/09/02/joint-statement-of-canadaand-the-kingdom-of-the-netherlands-regarding-intention-to-intervene-in-the-gambia-v.-myanmar-case-atthe-international-court-of-justice. The topic of intervention and community interest is outside the scope of this article (see, generally, Beatrice I. Bonafè, La protezione degli interessi di Stati terzi davanti alla Corte internazionale di giustizia (2014) pp. 199-205).

7 The Netherlands, "The Netherlands Holds Syria Responsible for Gross Human Rights Violations", 18 September 2020, https://www.government.n//latest/news/2020/09/18/the-netherlands-holds-syriaresponsible-for-gross-human-rights-violations.
} 
This study is written from the perspective of a generalist international lawyer. In light of its subject-matter, it devotes specific attention to the case-law of the ICJ and, in particular, to recent decisions in the Belgium v. Senegal case ${ }^{8}$ and the 2020 order in the pending The Gambia v. Myanmar case. The study focuses only on litigation before the ICJ, the principle judicial organ of the United Nations (UN), whereas litigation of community interests before other international courts and tribunals is referred to only in passing.

This article aims at providing a better understanding of the litigation of community interests before the ICJ, and at systematising the relevant case-law. The conclusions offer new perspectives on the potential of such litigations and on the still existing grey areas, which may be useful to increase state accountability for violations of fundamental international law rules.

\section{Community Interests in International Law: An Overview}

The emergence of community interests in several areas of international law after World War Two is a phenomenon that has attracted lots of attention in international scholarship, which has generally explored it from the perspective of the so-called humanisation of international law, ${ }^{9}$ and/or from that of the verticalisation of international society. ${ }^{10}$ Whatever perspective one adopts, it is today undisputed that, in certain areas, international law has left behind purely bilateral relations to embrace a perspective based on community interests. This shift is marked by the emergence of certain international law obligations which are owed toward all the states parties to a treaty (and, thus, are called erga omnes partes), or towards the international community as a whole (and, so,

\footnotetext{
${ }^{8}$ Questions relating to the Obligation to Prosecute or Extradite (Belgium v. Senegal), Judgment, I.C.J. Reports 2012, p. 422.

9 See, e.g., Meron, supra note 3; Antônio Augusto Cançado Trindade, International Law for Humankind: Towards a New Jus Gentium (3rd ed., 2020).

${ }^{10}$ See, generally, the essays collected in Paolo Picone, Comunità internazionale e obblighi erga omnes (3rd ed., 2013); Linos-Alexandre Sicilianos, "L'influence des droits de l'homme sur la structure du droit international, deuxième partie: Les conséquences structurelles de la hiérarchisation", 116 Revue Générale de Droit International Public (2012) pp. 245-51; Tullio Treves, "The Expansion of International Law, General Course on Public International Law (2015)", 398 Recueil des Cours (2019) p. 43. Compare with Ulf Linderfalk, "International Legal Hierarchy Revisited - The Status of Obligations Erga Omnes", 80 Nordic Journal of International Law (2011) p. $1 \mathrm{ff}$.
} 
they are identified as erga omnes). ${ }^{11}$ This section illustrates briefly how these obligations emerged and how they have come to be central in international law discourse.

Traditional international law is based on bilateralism, that is, on the idea that states are sovereign over portions of territory, and any interference on that sovereignty is regulated by a bilateral relationship modelled upon property rights in domestic law. ${ }^{12}$ Accordingly, international law has provided for a reciprocity-based legal framework that allows states to coordinate their interests as visible in the fields of diplomatic and consular law, treaty law, law on the treatment of foreigners, law of war (and of neutrality), and law on settlement of international disputes. ${ }^{13}$ It is important to stress that bilateralism does not relate to the form of a source of international obligation, but to its content. This means that multilateral treaties may very well embody bilateral obligations, in the sense that they can be seen as a bundle of purely "bilateralisable" obligations, in which the performance or breach of an obligation affects only one specific contracting state. ${ }^{14}$

Pure bilateralist conceptions of international obligations started losing their verve after World War One, when breaches of some treaties concluded to protect minorities in Europe were seen by some as affecting all the states parties. ${ }^{15}$ After World War Two, the idea that some international law obligations are owed to the entire community of states or to a specific group of states became commonplace. This approach became pervasive in the sense that elements of community interests may be found in almost every area of contemporary international law. ${ }^{16}$ For example, the maintenance of international peace and security was centralised with the creation of the UN Security Council, which is tasked, under Chapter VII of the Charter of the United Nations, with taking actions in respect to threats to the peace, breaches of the peace, and acts of aggression even without the

\footnotetext{
${ }^{11}$ See, generally, André de Hoogh, Obligations Erga Omnes and International Crimes (1996); Maurizio Ragazzi, The Concept of International Obligations Erga Omnes (1997); Christian J. Tams, Enforcing Obligations Erga Omnes in International Law (2005); Tomuchat and Thouvenin, supra note 3; Giorgio Gaja, "The Protection of General Interests in the International Community", 364 Recueil des Cours (2012) p. 9ff.; Picone, supra note 10; Eyal Benvenisti and Georg Nolte (eds.), Community Interests Across International Law (2018).

12 Philip Allott, Eunomia: New Order for a New World (1990) pp. 324-325.

${ }^{13}$ Simma, supra note 2, p. 229.

${ }^{14}$ In the law of the treaties, this topic was explored by Gerald Fitzmaurice in his Third Report on the Law of Treaties, UN Doc. A/CN.4/115, YILC, Vol. II, pp. 27-28.

15 See, generally, Santiago Villalpando, "Some Archaeological Explorations on the Birth of Obligations Erga Omnes", in M. Kamga and M.M. Mbengue (eds.), Liber Amicorum Raymond Ranjeva (2013) p. 623ff.; Tarcisio Gazzini, 'The Protection of Minorities at the Origins of the Notion of Erga Omnes Obligations", in A.R. Ziegler and J. Kuffer (eds.), Les Minorités et le Droit - Minorities and the Law (2016) p. 13ff.

${ }^{16}$ On specific areas, see the essays recently collected in Benvenisti and Nolte, supra note 11.
} 
consent of the states involved in the specific scenario; international humanitarian law conventions renounced bilateralism and introduced a number of mechanisms for monitoring compliance by states that were not party to a specific conflict; ${ }^{17}$ in the codification of the law of treaties, states recognised that some rules cannot be derogated because they are so important for the international community that they lay outside the treaty-making power of states (jus cogens); ${ }^{18}$ the use of the oceans must follow the idea that it is "common heritage" of humankind;"19 some cultural and natural heritage is not owned by the states where they are located but are "world heritage";20 the respect for some rules for the protection of the environment is placed in the interest of all the states of the world; 21 finally, the flourishing of universal and regional human rights conventions proves that the respect of human rights within one state is not the concern of that state only, but rather, the prevention and repression of violations affect all the states parties to those instruments. ${ }^{22}$ Even the litigation of inter-state disputes, traditionally seen as based on bilateralism, is today perceived as pursuing some community interests goals, not only for the procedural mechanisms (e.g., intervention) that allow the protection of third states' interests, ${ }^{23}$ but, more generally, for the proven function of ascertainment and promotion of international law beyond the solution of specific disputes. ${ }^{24}$

\footnotetext{
${ }^{17}$ See Marco Longobardo, "The Contribution of International Humanitarian Law to the Development of the Law of International Responsibility Regarding Obligations Erga Omnes and Erga Omnes Partes", 23 Journal of Conflict and Security Law (2018) pp. 433-434.

18 See Article 53 of the Vienna Convention on the Law of Treaties, 23 May 1969. In an endless sea of scholarship on this topic, see, e.g., Robert Kolb, Théorie du ius cogens international: Essai de relecture du concept (2001); Alexander Orakhelashvili, Peremptory Norms in International Law (2006); Tomuschat and Thouvenin, supra note 4; Daniel Costelloe, Legal Consequences of Peremptory Norms in International Law (2017); Ulf Linderfalk, Understanding Jus Cogens in International Law and International Legal Discourse (2020).

${ }^{19}$ See Article 136 of the United Nations Convention on the Law of the Sea, 10 December 1982. See Simma, supra note 2, pp. 240-242.

${ }^{20}$ Convention Concerning the Protection of the World Cultural and Natural Heritage, 16 November 1972. See, also, Francesco Francioni, "Beyond State Sovereignty: The Protection of Cultural Heritage as a Shared Interest of Humanity", 25 Michigan Journal of International Law (2004), p. $1209 \mathrm{ff}$.

${ }^{21} \mathrm{See}$, in relation to the obligations relating to preservation of the environment of the high seas and in the Area, Responsibilities and Obligations of States Sponsoring Persons and Entities with Respect to Activities in the Area, Advisory Opinion, I.T.L.O.S. Reports 2011, para. 180. Generally, see Simma, supra note 2, pp. 238240.

22 See the authors cited supra note 9.

${ }^{23}$ See, generally, Markus Benzing, "Community Interests in the Procedure of International Courts and Tribunals", 5 The Law \& Practice of International Courts and Tribunals (2006) p. $369 \mathrm{ff}$.

24 See, generally and for further references to this debate, Eyal Benvenisti, "Community Interests in International Adjudication", in Benvenisti and Nolte, supra note 11, p. $70 \mathrm{ff}$.
} 
This huge shift toward legal recognition of community interests intruded in the caselaw of the ICJ with the famous 1970 Barcelona Traction case. In an obiter dictum ripe with consequences for the development of international law, 25 the Court affirmed that:

$[A] n$ essential distinction should be drawn between the obligations of a State towards the international community as a whole, and those arising vis-à-vis another State in the field of diplomatic protection. By their very nature the former are the concern of all States. In view of the importance of the rights involved, all States can be held to have a legal interest in their protection; they are obligations erga omnes. ${ }^{26}$

The Court unmistakably asserted that bilateralism and community interest coexist in contemporary international law. Today, it is possible to define obligations erga omnes as those international obligations, usually customary in nature, whose implementation is the concern of every state since they are owed towards the international community as a whole, rather than towards one or more states.

Over the years, scholars have identified another category of community interests that pertain only to a specific group of states that are all parties to a certain treaty: obligations erga omnes partes. These obligations can be defined as obligations owed towards a specific group of states, all of which have an interest in compliance with them. In practice, obligations erga omnes partes are usually treaty obligations owed towards a group of contracting states bound by the same multilateral treaty, when all the parties have a legal interest in respecting the rules embodied therein. ${ }^{27}$

In both cases, the emphasis of these categories is on the holders of the legal interest to comply with a specific obligation: if there are only one or two reciprocal holders, the obligation is bilateral. If the holders are all the states of the international community, the obligation is erga omnes, if multiple holders belong to a distinguishable group of states (e.g., all the states parties to a specific treaty), the obligation is erga omnes partes. The emphasis on the holders of interests differentiates these obligations from jus cogens

\footnotetext{
${ }^{25}$ On the legacy of this dictum, see Christian J. Tams and Antonios Tzanakopoulos, "Barcelona Traction at 40: The ICJ as an Agent of Legal Development", 23 Leiden Journal of International Law (2010) p. 781 ff.; Erika De Wet, "Invoking Obligations Erga Omnes in the Twenty-first Century: Progressive Developments since Barcelona Traction", 38 South African Yearbook of International Law (2013) p. $19 \mathrm{ff}$.

${ }^{26}$ Barcelona Traction, Light and Power Company, Limited, Judgment, I.C.J. Reports 1970, p. 3., para. 33.

27 Generally, on the various kinds of international obligations, see Linos-Alexandre Sicilianos, "The Classification of Obligations and the Multilateral Dimension of the Relations of International Responsibility", 13 European Journal of International Law (2002) p. 1135.
} 
obligations, which is a notion related to the inderogability of a specific obligation. Yet, in practice, jus cogens rules usually entail obligations erga omnes. ${ }^{28}$

The UN ILC has included references to obligations erga omnes and erga omnes partes in its Draft Articles on State Responsibility (DARS) finalised in 2001.29 Article 42(b) considers that states 'specially affected' by violations of obligations 'owed to [... . a group of states including that state [obligations erga omnes partes], or the international community as a whole [obligations erga omnes]' are injured states under the law of international responsibility. Article 48(1) regulates the right of any state that is not characterised as injured under Article 42, in relation to violations of obligations 'owed to a group of states including that state, and [. . .] established for the protection of a collective interest of the group' (obligations erga omnes partes), and obligations 'owed to the international community as a whole' (obligations erga omnes). As analysed below, these Articles influenced the subsequent ICJ case law, even though the ICJ has never applied them directly.

The ICJ has relied explicitly on the notions of obligations erga omnes and erga omnes partes in a number of recent judgments and advisory opinions. This judicial activity helped with identifying and developing these categories. For instance, in the 1970 Barcelona Traction case, the Court considered that obligations erga omnes emerged "from the outlawing of acts of aggression, and of genocide, as also from the principles and rules concerning the basic rights of the human person, including protection from slavery and racial discrimination".30 Moreover, the Court affirmed that the principle of selfdetermination of peoples entails obligations erga omnes in the 1995 East Timor case, ${ }^{31}$ in the 2004 Wall opinion, ${ }^{32}$ and in the 2019 Chagos opinion. ${ }^{33}$ In the Wall opinion, the Court also affirmed that certain international humanitarian law rules entail obligations erga

\footnotetext{
28 José B. Acosta-Estévez, "Normas de ius cogens, efecto erga omnes, crimen internacional y la teoría de los círculos concéntricos", 11 Anuario de derecho internacional (1995) pp. 12-15; Denis Alland, "Countermeasures of General Interest", 13 European Journal of International Law (2002) p. 1237; Paolo Picone, "The Distinction between Jus Cogens and Obligations Erga Omnes", in E. Cannizzaro (ed.), The Law of Treaties Beyond the Vienna Convention (2011) p. 411ff.

${ }^{29}$ Draft Articles on Responsibility of States for Internationally Wrongful Acts with Commentaries (ILCY, vol. II, Part Two, [2001] 31) (DARS).

30 Barcelona Traction, supra note 26, para. 44.

${ }^{31}$ East Timor (Portugal v. Australia), Judgment, I.C.J. Reports (1995), p. 90, para. 29.

32 Legal Consequences of the Construction of a Wall in the Occupied Palestinian Territory, Advisory Opinion, I.C.J. Reports 2004, p. 136, para. 155.

${ }^{33}$ Legal Consequences of the Separation of the Chagos Archipelago from Mauritius in 1965, Advisory Opinion, I.C.J. Reports 2019, p. 95, para. 180.
} 
omnes $^{34}$ - a conclusion that was endorsed by a separate opinion of Judge Simma in the 2005 DRC v. Uganda case. ${ }^{35}$ After a very early allusion already in 1951, 36 the Court openly recognised that the obligations to prevent and punish genocide are erga omnes in the Barcelona Traction case, ${ }^{37}$ in the 2006 DRC v. Rwanda case, ${ }^{38}$ and in the 2007 Bosnia v. Serbia case; ${ }^{39}$ subsequent decisions, such as the 2015 Croatia v. Serbia case ${ }^{40}$ and the 2020 order in The Gambia v. Myamar case, ${ }^{41}$ have considered that the treaty obligations to prevent and punish genocide are obligations erga omnes partes. Similarly, the treaty obligations related to the prohibition and punishment of torture were considered to be erga omnes partes in the 2012 Belgium v. Senegal case ${ }^{42}$ and in the 2020 The Gambia v. Myamar order. ${ }^{43}$ Following a significant debate in international scholarship, ${ }^{44}$ environmental law rules have been recognised as a source of obligations erga omnes in a separate opinion appended by Judge Dugard to the Costa Rica v. Nicaragua case. ${ }^{45}$

Finally, the ICJ's dictum has influenced relevant case law of other international courts and tribunals, as well as international institutions tasked with the codification of international law. Obligations erga omnes have been debated, among others, by the International Tribunal for the Law of the Sea, ${ }^{46}$ the International Criminal Tribunal for the

\footnotetext{
34 Wall opinion, supra note 32, para. 155.

35 Armed Activities on the Territory of the Congo (DRC v. Uganda), Judgment, I.C.J. Reports 2005, p. 168, Separate Opinion of Judge Simma, para. 37.

36 Reservations to the Convention of Genocide, Advisory Opinion, I.C. J. Reports 1951, p. 15, p. 23:
}

In such a convention the contracting States do not have any interests of their own; they merely have, one and all, a common interest, namely, the accomplishment of those high purposes which are the raison d'être of the convention. Consequently, in a convention of this type one cannot speak of individual advantages or disadvantages to States, or of the maintenance of a perfect contractual balance between rights and duties.

37 Barcelona Traction, supra note 26, para. 44.

38 Armed Activities on the Territory of the Congo (New Application: 2002) (Democratic Republic of the Congo v. Rwanda), Jurisdiction and Admissibility, Judgment, I.C.J. Reports 2006, p. 6, рага. 64.

39 Application of the Convention on the Prevention and Punishmentof the Crime of Genocide (Bosnia and Herzegovina v. Serbia and Montenegro), Judgment, I.C.J. Reports 2007, p. 43, paras. 147 and 185 (where the Court did not challenge the qualification of obligations erga omnes provided by the applicant).

${ }^{40}$ Application of the Convention on the Prevention and Punishment of the Crime of Genocide (Croatia v. Serbia), Judgment, I.C.J. Reports 2015, p. 3, para. 87.

41 The Gambia v. Myanmar, supra note 5, para. 41.

42 Belgium v. Senegal, supra note 8, paras. 68-70.

43 The Gambia v. Myanmar, supra note 5, para. 41.

44 Compare, e.g., Paolo Picone, "Obblighi reciproci ed erga omnes degli Stati nel campo della protezione internazionale dell'ambiente marino", in V. Starace (ed.), Diritto internazionale e protezione dell' ambiente marino (1983) p. 32ff.; Malgosia Fitzmaurice, "International Protection of the Environment", 293 Recueil des 
Former Yugoslavia, ${ }^{47}$ and the European Court of Justice, ${ }^{48}$ while the Institut de Droit International spent several years trying to codify the rules governing the consequences of their violations. ${ }^{49}$

\section{The Standing of States Litigating Community Interests before the ICJ}

\subsection{Preliminary Observations}

This section explores the legal standing of indirectly injured states before the ICJ when they attempt to litigate community interest obligations. ${ }^{50}$ Indeed, the idea of obligations erga omnes and erga omnes partes implies that, in cases of violations, every state of the international community or of a specific treaty has an interest in other states' compliance with that rule. What it looks like a quite straightforward issue is, nonetheless, a highly controversial point before the ICJ. Not only did the Court take decades to acknowledge the standing of indirectly injured states in relation to violations of community interests,

Cours (2002) pp. 142-144; Malgosia Fitzmaurice, "The International Court of Justice and International Environmental Law", in Christian J. Tams and James Sloan (eds.), The Development of International Law by the International Court of Justice (2013) pp. 357-358; Malgosia Fitzmaurice, "Multilateralism, Community of Interests and Environmental Law" (unpublished, forthcoming, on file with the author).

45 Certain Activities Carried out by Nicaragua in the Border Area (Costa Rica v. Nicaragua), Question of Compensation, Judgment, I.C.J. Reports 2015, p. 15, Dissenting Opinion of ad hoc Judge Dugard, para. 35.

${ }^{46}$ See, e.g., Responsibilities and Obligations of States, supra note 21, para. 180.

47 See, e.g., Prosecutor v. Anto Furundzija, IT-95-17/1-T (10 December 1998) para. 151; Prosecutor v. A. Kupreskic et al., IT/95/16/T (14 January 2000) para. 517.

${ }^{48}$ Case $\mathrm{C} \square 104 / 16$ P, Council of the European Union v. Front POLISARIO, 21 December 2016, para. 88.

49 Institut de Droit International, Krakow session, Resolution of 27 August 2005.

50 See, e.g., Serena Forlati, "Azioni dinanzi alla Corte internazionale di giustizia rispetto a violazioni di obblighi erga omnes", 84 Rivista di Diritto Internazionale (2001) p. 69ff.; François Voeffray, L'actio popularis ou la défense de l'intérêt collectif devant les juridictions internationales (2004); Tams, supra note 11, pp. 158197; Mariko Kawano, "Standing of a State in the Contentious Proceedings of the International Court of Justice", 55 Japanese Yearbook of International Law (2012) p. 208ff.; Beatrice Bonafé, "La violation d'obligations envers la communauté internationale dans son ensemble et la compétence juridictionnelle de la Cour internationale de Justice", in E. Cannizzaro (ed), The Present and Future of Jus Cogens (2015) p. 145ff.; Farid Ahmadov, The Right of Actio Popularis before International Courts and Tribunals (2018); Giorgio Gaja, "Claims Concerning Obligations Erga Omnes in the Jurisprudence of the International Court of Justice", in R. Pisillo Mazzeschi and P. De Sena (eds.), Global Justice, Human Rights and the Modernization of International Law (2018) p. 39ff.; Maria Irene Papa, "La giurisprudenza della Corte internazionale di giustizia in materia di public interest litigation: luci ed ombre", in G. Contaldi et al. (eds.), Liber amicorum Angelo Davì (2019) p. 1933ff.; Mariana Ferolla Vallandro do Valle, "Legitimidade (Standing) perante a Corte Internacional de Justiça", in A. Dal Ri Júnior and L.C. Lima (eds.), A Jurisprudência da Corte Internacional de Justiça: História e influência no Direito Internacional (2020) p. 445ff.. 
but also, the latitude of their standing is still disputed, as demonstrated by the pending The Gambia v. Myanmar case. Indeed, notwithstanding the fact that the 2020 order on provisional measures has recognised the prima facie standing of The Gambia, ${ }^{51}$ this issue will be disputed at the merit stages.

Defining standing (also, jus standi or locus standi) in international law is not an easy task. $^{52}$ Standing may refer to two different issues: which entities can be parties to a dispute before a court, or which entities can bring a specific claim. ${ }^{53}$ The first question is answered by Article 34(1) of the ICJ Statute, which clarifies that "only states may be parties in cases before the Court". ${ }^{4}$ On the other hand, the ICJ is silent on the second question. Drawing on the experiences of national legal systems, in light of what is likely a general principle of law recognised by domestic legislations, it is possible to say that states have standing in relation to a specific dispute if they have a legal interest in the compliance with the international law rule at the centre of that dispute. ${ }^{55}$ The Permanent Court of International Justice emphasised this conclusion in the 1923 Wimbledon case, where it recognised the standing of the UK, France, Italy, and Japan against Germany, on the basis of Article 386(1) of the Treaty of Versailles, because all the applicants had an "intérêt évident" in the execution of some provisions regarding the navigation of the Kiel Canal.56 As demonstrated below, the ICJ has consistently maintained that standing pertains to the existence of a legal interest in relation to the solution of a particular dispute. However, this notion should be seen as applicable only to those international courts and tribunals whose statutes do not embody a special rule on standing. ${ }^{57}$ Indeed, some relevant statutes, such as Article 33 of the European Convention of Human Rights, may confer a right to bring a claim in relation to disputes for which states do not need to demonstrate any legal interest.

It should be also emphasised that, usually, the ICJ examines the issue of standing independently from that of jurisdiction. Although sometimes the delineations between

\footnotetext{
51 See The Gambia v. Myanmar, supra note 5, para. 42.

52 For some general works, see Kéba Mbaye, "L'intérêt pour agir devant la Cour internationale de justice", 209 Recueil des Cours (1988-2), p. 223ff.; Jean-Pierre Quéneudec, "La notion d'État intéressé en droit international", 225 Recueil des Cours (1995), p. 339ff.; Giorgio Gaja, "Standing: International Court of Justice (ICJ)", Max Planck Encyclopedia of International Procedural Law online (2018).

53 Gaja, supra note 52 , para. 1.

54 On this topic, see, generally, Angela Del Vecchio, Le parti nel processo internazionale (1975).

55 Mario Scerni, “La procédure de la Cour permanente de jusitce internationale”, 65 Recueil des Cours (1938) pp. 609-610; Mbaye, supra note 52, pp. 260-261.

56 Wimbledon, Merits, Judgment No. 1, 17 August 1923, PCIJ A 1, p. 20.

57 See Article 55 of the DARS, and the Commentary to Part Three, Chapter I, paragraph 5 of the DARS.
} 
the two concepts are ambiguous in practice, ${ }^{58}$ it is possible to consider, in wide brushstrokes, that issues of jurisdiction pertain to the power of the Court to adjudicate a specific dispute, whereas issues of admissibility pertain to the existence of bars to the exercise of the Court's jurisdiction. ${ }^{59}$ The addressing of standing in the framework of admissibility of cases is today unchallenged in the Court's practice. ${ }^{60}$

To tackle the complex issue of the standing of indirectly injured states before the ICJ, this article first explores the evolution of the ICJ case law, from early decisions in the sixties to the 2020 order in The Gambia v. Myanmar case. Then, the article goes on to emphasise some inconsistencies in the most recent case law, and to highlight some points that deserve more attention from the Court

\subsection{The Initial ICJ's Rejection of Indirectly Injured States' Standing in the Litigation of Community Interests (1962-1966)}

The first time the ICJ approached the issue of standing of indirectly injured states was in relation to the Northern Cameroons (Cameroon v. United Kingdom) case, in which the standing of Cameroon to bring a claim in relation of the population of an area later annexed by Nigeria was at stake. ${ }^{61}$ Since the claim, which was based on Article 19 of the expired 1946 Trusteeship Agreement for the Territory of the Cameroons under British Administration, did not contain any request for reparation, the Court dismissed it arguing that any decision on the merits of the case would have been without purpose at a time when the UK was no longer administrating the area. ${ }^{62}$ Accordingly, the Court found that deciding whether Cameroon had standing to bring a claim for the violation of the Trusteeship Agreement was unnecessary. ${ }^{63}$

\footnotetext{
58 See, generally, Yuval Shany, Questions of Jurisdiction and Admissibility before International Courts (2015) pp. 129-133.

59 Oil Platforms (Islamic Republic of Iran v. United States of America), Judgment, I.C. J. Reports 2003, p. 161, para. 29. See, also, Shany, supra note 58, pp. 47-51.

${ }^{60}$ See Belgium v. Senegal, supra note 8, paras. 64-70. On this aspect, see Juan José Quintana, Litigation at the International Court of Justice: Practice and Procedure (2015) pp. 22-24; Pok Yin S. Chow, "On Obligations Erga Omnes Partes", 52 Georgetown Journal of International Law (forthcoming), Section 5, available online on SSRN.

${ }^{61}$ Case concerning the Northern Cameroons (Cameroon v. United Kingdom), Preliminary Objections, Judgment of 2 December 1963, ICJ Reports 1963, p. 15.

62 Ibid., pp. 35-38.

63 Ibid., p. 35. See the remarks by Forlati, supra note 50, pp. 84-86.
} 
The ICJ addressed directly the issue of standing in the infamous South West Africa cases. The dispute originated from the decision of Ethiopia and Liberia to convene South Africa before the ICJ in relation to the violation of the Mandate Agreement for South West Africa. The Court adopted different approaches regarding the standing of the two states in the preliminary objection decision and in the merit decision. In 1962, arguing from the perspective of the continuity between obligations under the League of Nations and the UN, the Court declared that the two states had standing64 since "the only effective recourse for protection of the sacred trust would be for a Member or Members of the League [of Nations] to invoke Article 7 and bring the dispute" so that "Article 7 was intended to play as one of the securities in the Mandates System for the observance of the obligations by the Mandatory". ${ }^{65}$

However, in 1966, the Court, in a different composition and thanks to the casting vote of the president, argued that in international law there is no "equivalent of an actio popularis, or right resident in any member of a community to take legal action in vindication of a public interest', 66 but rather, standing can only be derived from "rights or interests ... clearly vested in those who claim them, by some text or instrument, or rule of $1 a w^{\prime \prime 67}$ - a condition that, in the Court's view, was not fulfilled by Ethiopia and Liberia "under any of the relevant instruments, or as a constituent part of the mandates system as a whole, or otherwise". ${ }^{6}$

\subsection{The Cautious Approach of the ICJ in the Wake of Barcelona Traction (1970-2011)}

The South West Africa conclusion was at the centre of such a significant debate, both because of the quality of the reasoning and the U-turn from the preliminary objection to the merit phase, that most authors consider the aforementioned Barcelona Traction dictum in 1970 as a way for the Court to offer a remedy ${ }^{69}$ Indeed, in the Barcelona Traction case there was no need to address obligations erga omnes. Yet, the Court took the

\footnotetext{
${ }^{64}$ South West Africa Cases (Ethiopia v. South Africa; Liberia v. South Africa), Preliminary Objections, Judgment, ICJ Report 1962, p. 319, pp. 337-342.

65 Ibid., p. 337.

${ }^{66}$ South West Africa, Second Phase, Judgment, ICJ Reports 1966, p. 6, para. 88.

67 Ibid., para. 44.

$68 \mathrm{lbid}$.

${ }^{69}$ See, e.g., Jean Charpentier, "L'affaire de la Barcelona Traction devant la Cour internationale de Justice (arrêt du 5 février 1970)", 16 Annuaire Français de Droit International Année (1970) p. 312; Tams and Tzanakopoulos, supra note 25, pp. 792 and 799; Gaja, supra note 50, p. 40.
} 
opportunity to clarify that community interests, in the form of obligations erga omnes, do exist. As pointed out by the ICJ Judge Schwebel in a famous dissenting opinion, the South West Africa case was "rapidly and decisively displaced by the Court's Judgment in Barcelona Traction."70

Nevertheless, in Barcelona Traction, the Court was not asked to decide on a question of standing regarding litigation of community interests and, for decades, no litigation of public interests was brought before the ICJ. Indeed, the celebrated dictum was scrutinised in detail by scholars, who debated whether the Court referred to the issue of the standing or not. ${ }^{71}$ Few were able to grasp the apparently logical conclusion offered subsequently by Judge Higgins, according to which the "dictum was directed to a very specific issue of jurisdictional locus standi" ${ }^{72}$ Indeed, the fact that an obligation is owed to the "international community as a whole" is not in conflict with the fact that, in cases of violations, individual states are entitled to act to protect that interest: irrespective of its conceptualisation, the notion of an international community is a reality of contemporary legal discourse ${ }^{73}$ that needs the action of individual states to be operationalised, just as states need the action of human organs to exercise their rights. ${ }^{74}$ Nonetheless, when Australia and New Zealand brought a case against France in relation to nuclear tests, they mentioned the erga omnes nature of the ban of nuclear tests, ${ }^{75}$ claiming, however, that they had standing because of the impact of nuclear tests over their territories. ${ }^{76}$ Although the ICJ did not address the question of whether Australia and New Zealand had standing, the overall impression was that their litigations cannot be considered as commenced by indirectly injured states. ${ }^{77}$

\footnotetext{
70 Military and Paramilitary Activities in and Against Nicaragua (Nicaragua v. USA), Provisional Measures, I.C.J. Reports 1984, Dissenting Opinion of Judge Schwebel, p. 197.

${ }^{71}$ See the arguments examined by Tams, supra note 11, pp. 158-179.

72 Wall opinion, supra note 32, Separate opinion of Judge Higgins, para. 37.

${ }^{73}$ See Dupuy, supra note 4, p. 1079.

${ }^{74} \mathrm{See}$, also for further references, Santiago Villalpando, L'émergence de la communauté internationale dans la responsabilité des États (PUF 2005); Julio Barboza, "Legal Injury: The Tip of the Iceberg in the Law of State Responsibility?", in Maurizio Ragazzi (ed.), International Responsibility Today: Essays in Memory of Oscar Schachter (2005) p. 20; Costelloe, supra note 18, pp. 30-33.

75 Nuclear Tests (Australia v. France), Memorial on Jurisdiction and Admissibility submitted by the Government of Australia, 23 November 1973, paras. 431, 448; Nuclear Tests (New Zealand v. France), Application instituting proceedings, 9 May 1973, para. 28.

76 Nuclear Tests (New Zealand v. France), Application instituting proceedings, supra note 75, paras. 12-22; Nuclear Tests (Australia v. France), Application Instituting Proceedings, 9 May 1973, paras. 46-49.

77 See Christian J. Tams, "Roads Not Taken, Opportunities Missed: Procedural and Jurisdictional Questions Sidestepped in the Whaling Judgment", in M. Fitzmaurice and D. Tamada (eds.), Whaling in the Antarctic: Significance and Implications of the ICJ Judgment (2016) pp. 204-205; Yoshifumi Tanaka, "Reflections on
} 
After Barcelona Traction, the main references to obligations erga omnes were made to enlarge the jurisdiction of the ICJ rather than to base a particular standing in relation to the violation of community interests. For instance, in the 1995 East Timor case, the Court clarified that the necessity of the parties' consent to the Court's jurisdiction, and the corollary of the principle of the indispensable third-party, cannot be circumvented even in cases of litigations on violations of obligations erga omnes. ${ }^{78}$ The ICJ reached the same conclusion in the 2006 DRC v. Rwanda case, stressing that the interest to bring a claim in respect of violations of obligations erga omnes can only be analysed if the Court has jurisdiction under the usual consent-based rules. ${ }^{79}$ Similarly, in the Georgia v. Russia case, the nature of obligations erga omnes of the rules against racial discrimination was only mentioned by Georgia in response to an explicit question by Judge Cançado Trindade: in its answer, Georgia tried to argue that the nature of the obligations should have guided a broader interpretation of the compromissory clause included in the Convention Against Racial Discrimination ${ }^{80}$ - an argument that was eventually rejected when the Court dismissed the case because of lack of jurisdiction. ${ }^{81}$ Moreover, the issue of standing was avoided in the 2007 Bosnia v. Serbia case, when the Court said that Bosnia did not prove sufficiently that acts of genocide against non-Bosnian individuals occurred, ${ }^{82}$ thus rendering moot the question on whether Bosnia had standing in relation to them too. 83

Although some international lawyers were disappointed by these conclusions, and one even argued that nothing had changed since the South West Africa cases, ${ }^{84}$ these judicial developments do not impact the issue of standing. Indeed, the ICJ's conclusions

Locus Standi in Response to a Breach of Obligations Erga Omnes Partes. A Comparative Analysis of the Whaling in the Antarctic and South China Sea Cases", 17 Law and Practice of International Courts and Tribunals (2018) p. 532.

${ }^{78}$ East Timor case, supra note 32, para. 29.

${ }^{79}$ DRC v. Rwanda, supra note 38, para. 64. See, also, Croatia v. Serbia, para. 40, para. 88.

80 See Application of the International Convention on the Elimination of All Forms of Racial Discrimination (Georgia v. Russian Federation), GR 2010/19, 24 September 2010, pp. 3-4, reproduced in Application of the International Convention on the Elimination of All Forms of Racial Discrimination (Georgia v. Russian Federation), Preliminary Objections, Judgment, I.C.J. Reports 2011, p. 70, Dissenting opinion of Judge Cançado Trindade, para. 74.

81 See the reconstruction by Gleider I. Hernández, "A Reluctant Guardian: The International Court of Justice and the Concept of 'International Community", 83 British Yearbook of International Law (2013) p. 48, note 190.

82 See Bosnia v. Serbia, supra note 39, para. 368.

83 See Kawano, supra note 50, pp. 229-230; Gaja, supra note 52, para. 23.

${ }^{84}$ Ignacio de la Rasilla del Moral, "Nihil Novum Sub Sole Since the South West Africa Cases? On Ius Standi, the ICJ and Community Interests", 10 International Community Law Review (2008) p. $171 \mathrm{ff}$. 
in these cases pertain to the existence of the jurisdiction of the Court rather than to the impossibility to exercise it due to a ground of inadmissibility related to lack of standing. The issues of whether the Court has jurisdiction to adjudicate a dispute and of whether the claimant has standing to bring that specific claim run in parallel, and only the latter pertains to the holders of the interests to comply with a specific rule. ${ }^{85}$ Accordingly, the precedents of the ICJ dismissing cases for lack of jurisdiction notwithstanding the invocation of obligations erga omnes did not constitute precedents that indicate a reluctance of the Court in acknowledging the standing of indirectly injured states. ${ }^{86}$ Rather, it is noteworthy that occasionally, during these proceedings, states had the opportunity to offer evidence of opinio juris that indirectly injured states have standing in relation to the violation of community interests. For instance, Georgia recognised "the standing of all members of the international community to invoke the responsibility of the State for breach of erga omnes norms". 87

\subsection{The Role of the Codification of Rules of International Law Pertaining to State} Responsibility (1970-2005)

To dispel any overly pessimistic outlooks surrounding this period, it should be noted that, over the same years, the very issue of indirectly injured states' standing in relation to violations of obligations erga omnes and erga omnes partes was clearly emerging in the working of two prestigious institutions tasked with the codification of customary international law: the UN ILC and the Institute de Droit International. The conclusion of the codification of the law on state responsibility by the ILC and, in particular, the references to the right to invoke responsibility for violations of obligations erga omnes and erga omnes partes in Article 48 of the DARS, paved the way to further litigations.

Under Article 48, indirectly injured states are entitled to 'invoke the responsibility' of another state. The commentary of Article 48 clarifies that "Article 48 is based on the idea that in case of breaches of specific obligations protecting the collective interests of a group of States or the interests of the international community as a whole, responsibility may be invoked by States which are not themselves injured in the sense of article

\footnotetext{
85 See Thouvenin, supra note 3, p. 328.

${ }^{86}$ See the detailed analysis of Tams, supra note 11, pp. 179-196, and his conclusions at p. 197. See, also, Orakhelashvili, supra note 18, pp. 518-527.

87 Georgia v. Russian Federation, GR 2010/19, supra note 80, pp. 3-4.
} 
42." ${ }^{88}$ According to the ILC, this right "should be understood as taking measures of a relatively formal character, for example, the raising or presentation of a claim against another state or the commencement of proceedings before an international court or tribunal". ${ }^{89}$ Although this expression is found in the commentary under Article 42, there is no reason to interpret it differently in relation to Article 48 . However, this conclusion may raise some concerns: whereas the invocation of responsibility under Article 42 is solidly based on a traditional understanding of customary international law on state responsibility, which is strictly related to the possibility to invoke a material breach of a treaty under Article 60 of the VCLT, the rule under Article 48 has less solid bases, and has no counterpart in the law of treaties. ${ }^{90}$

Nevertheless, from the standpoint of the ILC, a state can bring a claim before an international court to litigate community interests. This conclusion was clarified by the ILC's Special Rapporteur James Crawford, who confirmed that Article 48 of the DARS governs standing. ${ }^{91}$ Indeed, it is important to stress that, while some authors have questioned the correspondence to customary international law of the whole Article 48 of the DARS, ${ }^{92}$ in the view of the ILC, only the possibility to claim reparation on behalf of the injured state or other beneficiary of the breach rule under Article $48(2$ (b) is a measure of progressive development. ${ }^{93}$ Accordingly, already in 2001, the ILC strongly supported the idea that standing can be based on Article 48 as well, as a matter of customary international law.

The conclusion that an indirectly injured state can bring a claim for the violation of obligations erga omnes and erga omnes partes was forcefully advocated by the Institut de Droit International as well, which adopted in 2005 a resolution on obligations erga omnes. Based on the works of the special rapporteur Giorgio Gaja, the resolution encompasses both obligations erga omnes and erga omnes partes, ${ }^{94}$ and clearly affirms that "in the event of there being a jurisdictional link between a State alleged to have committed a breach of an obligation erga omnes and a state to which the obligation is owed, the latter state has

\footnotetext{
88 Commentary to Article 48, para. 2.

${ }^{89}$ Commentary to Article 42, para. 2.

90 See Malgosia Fitzmaurice, "International Responsibility and Liability", in D. Bodansky, J. Brunnée and E. Hey (eds.), The Oxford Handbook of International Environmental Law (2008) p. 1021.

91 See, e.g., Crawford, supra note 1, p. 232.

92 See, e.g., Edith Brown Weiss, "Invoking State Responsibility in the Twenty-First Century", 96 American Journal of International Law (2002) p. 808; Fitzmaurice, supra note 90, p. 1021.

93 Commentary to Article 48, para. 12.

94 Institut de Droit International, supra note 49, Article 1.
} 
standing to bring a claim to the International Court of Justice or other international judicial institution in relation to a dispute concerning compliance with that obligation".95 This conclusion reinforced the ILC's position and paved the way for actual litigation before the ICJ by indirectly injured states.

\subsection{From the Revolutionary Belgium v. Senegal Case to The Gambia v. Myanmar and Beyond}

The first case in which the ICJ recognised the standing of indirectly affected states in relation to litigating community interests is the 2012 Belgium v. Senegal case. The dispute originates from an application issued by Belgium under Article 30 of the 1984 UN Convention Against Torture, in which Belgium alleged that Senegal was violating its obligation to prosecute or extradite for torture Hissène Habré. The Belgian involvement in the case originated by a request from Belgian judicial authorities to Senegal to extradite Hissène Habré in order to prosecute him for crimes against humanity. ${ }^{96}$ In response to the objections by Senegal regarding the standing of Belgium, the Court affirmed that

The common interest in compliance with the relevant obligations under the Convention against Torture implies the entitlement of each State party to the Convention to make a claim concerning the cessation of an alleged breach by another State party. If a special interest were required for that purpose, in many cases no State would be in the position to make such a claim. It follows that any State party to the Convention may invoke the responsibility of another State party with a view to ascertaining the alleged failure to comply with its obligations erga omnes partes ... and to bring that failure to an end. ${ }^{97}$

\footnotetext{
95 Ibid., Article 3.

96 The relevant facts are summarised Belgium v. Senegal, supra note 8, paras. 15-41.

${ }^{97}$ Ibid., para. 69. For different views on this conclusion, see Maria Irene Papa, "Interesse ad agire davanti alla Corte internazionale di giustizia e tutela dei valori collettivi nella sentenza sul caso Belgio c. Senegal", 7 Diritti umani e diritto internazionale (2013) p. 79ff.; Joe Verhoeven, "Belgique contre Sénégal ou quel intérêt pour se plaindre d'autrui? Cour internationale de Justice, 20 juillet 2012, Questions concernant l'obligation de poursuivre ou d'extrader", 59 Annuaire Français de Droit International (2013) p. 3ff.
} 
The Court thus recognised the standing of Belgium based on the erga omnes partes character of the obligations at the centre of the dispute, overruling the conclusions of the South West Africa cases.

The Belgium v. Senegal case triggered a cascade effect: indirectly injured states have been prompter to litigate community interests before the ICJ, and respondent states have hesitated in disputing the standing of the claimant in certain litigations concerning community interests. For instance, in the course of the 2014 Australia v. Japan case on whaling before the ICJ, Japan decided not to challenge Australian standing so that the Court did not have to address the issue, even though the dispute over whaling concerned activities outside the waters of Australia. ${ }^{98}$ Moreover, the Marshall Islands claimed standing on the basis of obligations erga omnes partes allegedly embodied in Article 6 of the 1968 Non-Proliferation of Nuclear Weapons Treaty and in the allegedly corresponding customary obligations erga omnes in a series of cases against Pakistan, India, and UK, which were controversially ${ }^{99}$ dismissed on the different ground of the lack of a dispute. ${ }^{100}$

Moreover, the Belgium v. Senegal case likely affected international litigations also before other international tribunals as well. For instance, it has been argued that the precedent of Belgium v. Senegal played a role also in the South China Sea arbitration between the Philippines and China, ${ }^{101}$ where the arbitral tribunal created under Annex VII of the UNCLOS scrutinised also some Chinese activities outside the Philippine waters and, thus, from a purely bilateralist perspective, for which Philippines should have had no standing. ${ }^{102}$ The Netherlands invoked the Belgium v. Senegal case to support its standing in the Arctic Sunrise arbitral proceedings under Annex VII of the UNCLOS, where the

\footnotetext{
${ }^{98}$ See Malgosia Fitzmaurice, Whaling and International Law (2015) pp. 109-13; Tams, supra note 77, pp. 201211; Tanaka, supra note 77, pp. 535-545. The ICJ decided the case on Whaling in the Antarctic (Australia $v$ Japan: New Zealand intervening), Judgment, I.C.J. Reports 2014, p. 226.

${ }^{99}$ See, e.g., Vincent-Joël Proulx, "The World Court's Jurisdictional Formalism and its Lost Market Share: The Marshall Islands Decisions and the Quest for a Suitable Dispute Settlement Forum for Multilateral Disputes", 30 Leiden Journal of International Law (2017) p. 925ff.

100 Obligations concerning Negotiations relating to Cessation of the Nuclear Arms Race and to Nuclear Disarmament (Marshall Islands v. Pakistan), Application instituting proceedings against Pakistan, paras. 3536; Obligations concerning Negotiations relating to Cessation of the Nuclear Arms Race and to Nuclear Disarmament (Marshall Islands v. India), Application instituting proceedings against the Republic of India, paras. 40-41; Obligations concerning Negotiations relating to Cessation of the Nuclear Arms Race and to Nuclear Disarmament (Marshall Islands v. UK), Application instituting proceedings against the UK, paras. 8586. See the remarks by Papa, supra note 50, pp. 1947-1948, note 40.

101 The South China Sea Arbitration Award (Merits) (the Republic of Philippines v. the People's Republic of China), Award of 12 July 2016.

102 Tanaka, supra note 77, pp. 545-553.
} 
Netherlands claimed to have standing for alleged violations of the freedom of navigation by Russia both as directly affected state and as a result of the nature of obligations erga omnes partes of the breached rules. ${ }^{103}$ However, in the former case the non-participation of China to the proceedings resulted in lack of contestation of the standing claimed by the Philippines and in the silent approval of it by the Arbitral Tribunal, ${ }^{104}$ whereas in the latter, the Arbitral Tribunal concluded that, since the Netherlands has standing as injured states, there was no need to investigate the claim based on obligations erga omnes partes. ${ }^{105}$

The reasoning in the Belgium v. Senegal case was directly quoted as the decisive precedent in the 2020 Gambia v. Myanmar order on provisional measures. The Gambia claimed its standing in relation to alleged violations of the UN Genocide Convention by Myanmar, in relation to the governmental actions against the Rohingya minority, on the assumption that the relevant rules are obligations erga omnes partes. ${ }^{106}$ In its order on provisional measures, the Court, taking into account the fact that both the UN Convention Against Torture and the UN Genocide Convention embody obligations erga omnes partes, acknowledged the standing of The Gambia without further elaboration. ${ }^{107}$ Interestingly, Myanmar did not contend that The Gambia had no legal interest to bring the claim, but rather, only argued that the Court should prioritise the standing of Bangladesh, which is, in Myanmar's view, the directly injured state. ${ }^{108}$ Irrespective of the merits of this objection, ${ }^{109}$ it is important to emphasise that even an alleged perpetrator of a violation of an obligation erga omnes partes recognises the legal interests of all the states parties to the relevant convention. This could be seen as a further consequence of the strong impact that the Belgium v. Senegal case had on judicial strategy.

Going back to The Gambia v. Myanmar order, it should be noted that, at this stage, the Court did not elaborate the legal bases of the standing of The Gambia in detail, ${ }^{110}$ as

\footnotetext{
103 The Arctic Sunrise Arbitration (Netherlands v. Russia), Memorial of the Kingdom of the Netherlands, 31 August 2014, para. 118.

104 Generally, issues of standing are not raised by courts proprio motu (see Gaja, supra note 52, para. 29).

105 The Arctic Sunrise Arbitration (Netherlands v. Russia), Award of 14 August 2015, para. 186.

106 The Gambia v. Myanmar, Application instituting proceedings and Request for the indication of provisional measures, 11 November 2019, paras. 121-127.

107 See The Gambia v. Myanmar, supra note 5, paras. 41-42.

108 Ibid.

${ }^{109}$ See infra, section 4.3, for more on this.

110 See the early comments by Priya Pillai, "ICJ Order on Provisional Measures: The Gambia v Myanmar", OpinioJuris (24 January 2020), https://opiniojuris.org/2020/01/24/icj-order-on-provisional-measures-thegambia-v-myanmar/; Michael A. Becker, "The Plight of the Rohingya: Genocide Allegations and Provisional
} 
appropriate in answering a request for preliminary measures. Indeed, the conclusions of the order are not the last words on the standing of The Gambia in these proceedings, but rather, they do not acquire the force of res judicata. As clarified by the Court, "the decision given in the present proceedings in no way prejudges the question of the jurisdiction of the Court to deal with the merits of the case or any questions relating to the admissibility of the Application or to the merits themselves."111 This means that the issue of standing will be addressed in the merits phase. As demonstrated in the section below, some clarification is much needed.

\section{Grey Areas in the ICJ's Case Law over the Standing of Indirectly Injured States in Litigating Community Interests}

\subsection{Preliminary Remarks}

From the analysis of the aforementioned case law it is possible to deduce some points that appear to be well-settled, and to envisage some grey areas regarding the standing of indirectly injured states in relation to litigation of community interests before the ICJ. The analysis in the following subsections will address in particular whether violations of obligations erga omnes and obligations erga omnes partes are treated equally in relation to standing of indirectly injured states, the need of a special interest to bring claims regarding community interests, and the relationship between the ICJ case law and the ILC's codification.

\subsection{The Standing of Indirectly Injured States and Breaches of Different Kinds of Community Obligations}

\footnotetext{
Measures in The Gambia v Myanmar at the International Court of Justice", 21 Melbourne Journal of International Law (2020), Section 4(1), available online via SSRN; Carlos Espaliú Berdud, "Locus Standi of States and Erga Omnes Obligations in the Contentious Jurisdiction of the International Court of Justice", 72 Revista Española de Derecho Internacional (2020) p. 33ff.; Maria Irene Papa, "La tutela degli interessi collettivi nell'ordinanza sulle misure provvisorie nel caso Gambia c. Myanmar", 103 Rivista di Diritto Internazionale (2020) p. 729ff.; Rosario Huesa Vinaixa, "Una controversia bilateral con dimensión multilateral: cuestiones de jurisdicción y de ius standi en el asunto Gambia c. Myanmar (medidas provisionales)", Revista Electrónica de Estudio Internacionales (1/2020).

111 The Gambia v. Myanmar, supra note 5, para. 85.
} 
An overview on the case law of the ICJ demonstrates that the Court today recognises that standing to bring a claim exists beyond a pure bilateralist approach, taking into account the fact that, in the contemporary international community, the implementation of certain obligations is in the interest of a plurality of states. This trend can be seen either as overruling the precedent set in the South West Africa cases or, rather, as a refinement and expansion of that position. Indeed, when the Court said that the entitlement to bring a claim should be "clearly vested in those who claim them, by some text or instrument, or rule of law", 112 it did not close the door to litigation by indirectly injured states, but rather, it just said that this is not possible for all obligations, but only for some specific ones under both treaty or customary law. ${ }^{113}$ From this perspective, some subsequent ICJ's decisions can be seen as an effort to identify those obligations that, when breached, can be at the centre of litigation on community interests.

The pool of norms that, if violated, can give rise to litigation of community interests is quite uniform. As seen, they are rules protecting fundamental rights of the human being, such as the ban on torture, the ban on genocide, certain rules of international humanitarian law, and the principle of self-determination of peoples. In this, there is a clear continuity between the contentious case law of the ICJ, when issues of standing are debated, and its advisory function, when obligations erga omnes and erga omnes partes are addressed in relation to other issues.

Less clear is whether the ICJ recognises standing to indirectly injured states in relation to obligations erga omnes, too, rather than just in relation to obligations erga omnes partes. Indeed, the Court carefully characterised the obligations under the UN Convention Against Torture as obligations erga omnes partes in the Belgium v. Senegal case, ${ }^{114}$ changing its classification of obligations under the UN Genocide Convention from obligations erga omnes (in the DRC v. Rwanda ${ }^{115}$ and Bosnia v. Serbia cases ${ }^{116}$ ) to obligations erga omnes partes in the Croatia v. Serbia case ${ }^{117}$ and The Gambia v. Myanmar order $^{118}$ (the latter, the only one relevant for the analysis of standing).

If these characterisations mean that the Court does not recognise any standing to indirectly injured states for violations of obligations erga omnes, the consequences may

\footnotetext{
112 South West Africa, Second Phase, supra note 66, para. 44.

113 Voeffray, supra note 50, pp. 70-71; Tanaka, supra note 77 p. 531.

114 Belgium v. Senegal, supra note 8, paras. 68-70.

115 DRC v. Rwanda, supra note 38, para. 64.

116 Bosnia v. Serbia, supra note 39, paras. 147 and 185.

117 Croatia v. Serbia, supra note 40, para. 87

118 The Gambia v. Myanmar, supra note 5, para. 41.
} 
be momentous. The fact that all the obligations erga omnes mentioned by the ICJ are, at the same time, obligations erga omnes partes embodied in specific multilateral treaties, including the principle of self-determination of peoples under Article 1 of the 1966 International Covenant on Civil and Political Rights, should not obscure the reality that "two rules of the same content are subject to separate treatment as regards the organs competent to verify their implementation, depending on whether they are customary rules or treaty rules". ${ }^{119}$ Accordingly, if the Court intended to exclude legitimisation of indirectly injured states for violations of obligations erga omnes, standing would be reserved only to states parties to some treaties. This would mean that, e.g., a state could not bring a claim for the violation of the ban of torture unless both claimant and respondent are parties to a multilateral treaty banning torture and have given jurisdiction over disputes related to that treaty to the ICJ. In other words, restricting the standing of indirectly injured states only to violations of obligations erga omnes partes reduces the revolutionary weight of litigation in the community interests, excluding any claim under customary international law.

The mere fact that the ICJ has never recognised standing on the basis of violations of obligations erga omnes could suggest that the Court prefers to rely on treaty obligations erga omnes partes only. ${ }^{120}$ Moreover, The Gambia itself, one of the very proponents of litigation of community interests, argued that the South West Africa cases were dismissed because Ethiopia and Liberia were not party to the relevant treaty (the Mandate Agreement), ${ }^{121}$ thus suggesting that the only relevant category is that of obligations erga omnes partes. Indeed, some authors have opposed the equation between obligations erga omnes and erga omnes partes in relation to standing before the ICJ, noting that the characterisation as obligations erga omnes pertains to the substance of the rights at stake, whereas the ICJ's notion of obligations erga omnes partes is incorrectly based - from their perspective - on the structure of the relevant sources (multilateral treaties). ${ }^{122}$

\footnotetext{
119 Military and Paramilitary Activities in and against Nicaragua (Nicaragua v. USA), Merits, Judgment. I.C.J. Reports 1986, p. 14, para. 178.

120 See Tams, supra note 11, pp. 310-311; Bonafé, supra note 50, p. 151; Papa, supra note 50, p. 1947.

121 The Gambia v. Myanmar, Verbatim Record, 11 December 2019, Remarks by P. Sands, para. 4.

122 See Diego Germán Mejía-Lemos, “On 'Obligations Erga Omnes Partes' in Public International Law: 'Erga Omnes' or 'Erga Partes'?", 10 Ars Boni et Aequi (2014) p. 177ff. For more criticisms, see Paolo Picone, "La responsabilità degli Stati tra codificazione e sviluppo progressivo della materia", 99 Rivista di Diritto Internazionale (2016) pp. 756-758.
} 
Nevertheless, a contrary argument can be based on the fact that, in the case law of the ICJ, obligations erga omnes and erga omnes partes are similar, in the sense that both characterisations pertain to the holders of the relevant interests. Accordingly, it might be argued that both categories involve standing in cases of violations to indirectly injured states. Indeed, the ITLOS mentioned obligations erga omnes when addressing the issue of standing, rather than obligations erga omnes partes only. ${ }^{123}$ Even the ILC, in the text of Article 48 of the DARS, does not make any distinction between invocation of responsibility regarding violations of obligations erga omnes and obligations erga omnes partes. Therefore, some authors contend that there is no reason why the ICJ would reject the standing of a claim by a indirectly injured state for the violation of an obligation erga omnes, if the Court has jurisdiction. ${ }^{124}$ As noted by Crawford, since "it is nonsensical if the 'party' to which the obligation is owed is a collective one without the capacity to act", 125 it is necessary to conclude that, in the case of violations of obligations erga omnes, "every State has standing". 126 This view is confirmed by the conclusion of the Institut de Droit International, which attributed standing in cases of violations of both categories, without any distinction. ${ }^{127}$

The logical conclusion that not only violations of obligations erga omnes partes, but also violations of obligation erga omnes, legitimises indirectly injured states to bring a claim before the ICJ, however, has not yet been confirmed by the Court.

\subsection{The Issue of the Need of a Special Interest}

Another point of uncertainty is the requirement of any special interest to bring a claim in the litigation of community interests. In the ILC's codification, the existence of a special interest is addressed by Article 42(b)(i) of the DARS, whereas the legitimation of indirectly injured states without a special interest is based on Article 48(1). So far, in its case law, the ICJ has largely overlooked this question, keeping an ambivalent position on whether the standing of the state was based on a special interest or not. Accordingly, the

\footnotetext{
123 Responsibilities and Obligations of States, supra note 21, para. 180.

124 See, e.g., Gaja, supra note 50, p. 45; Espaliú Berdud, supra note 110, pp. 45-49.

125 James Crawford, "Chance, Order, Change: The Course of International Law, General Course on Public International Law", 365 Recueil des Cours (2013) p. 202.

126 lbid.

127 See Institute de Droit International, supra note 49, Articles 1 and 3.
} 
parallelism drawn by the Court between the situations of Belgium $v$. Senegal and The Gambia v. Myanmar needs to be further substantiated at the merits stage.

In Belgium v. Senegal, Belgium had a special interest in the Senegalese compliance with the obligation to extradite or to prosecute suspects of torture because some victims were Belgians and as a Belgian judge had requested Senegal to extradite Habré. As a result, the main basis of standing advanced by Belgium is its quality of specially affected state under Article 42 of the DARS. In the words of the Belgian counsel,

Belgium is not simply a "State other than an injured State" within the meaning of Article 48 of the Articles on State Responsibility $\square$ even if this characterization is sufficient to invoke the responsibility of Senegal. The Belgian State is "affected by the breach in a way which distinguishes it from the generality of other States to which the obligation is owed". On the one hand, the Belgian courts are actively seised of the $H$. Habré case as a result of the complaints filed in 2000; some of the victims are of Belgian nationality. On the other hand, Belgium has formally requested Mr. Habré's extradition on the basis of the aut dedere aut judicare obligation under the 1984 Convention and customary international law. Belgium therefore has a special interest in Mr. Habré being extradited or, failing that, tried in Senegal, or in other words, in Senegal complying with its international commitments. ${ }^{128}$

Accordingly, read from this perspective, the Belgium v. Senegal case does not support the standing of indirectly injured states, but only that of directly injured ones (i.e., states specially affected). Indeed, the Court eluded the issue of the Belgian special interest by arguing that:

Belgium, as a State party to the Convention against Torture, has standing to invoke the responsibility of Senegal. Therefore, the claims of Belgium based on these provisions are admissible. As a consequence, there is no need for the Court to pronounce on whether Belgium also has a special interest with respect to Senegal's compliance with the relevant provisions of the Convention. ${ }^{129}$

\footnotetext{
${ }^{128}$ Belgium v. Senegal, Memorial of the Kingdom of Belgium, 1 July 2010, para. 5.17 (references omitted).

${ }^{129}$ Belgium v. Senegal, supra note 8, para. 70.
} 
This sentence does not say anything about the legal basis of the Belgian standing, on whether it is grounded on Article 42 or on Article 48 of the DARS. Moreover, the Court does not clarify whether the decision of overlooking the issue of a special interest is relevant only for that specific case or, whether, it is valid in other similar cases. Simply, the Court merged the two arguments, maintaining that there was no need to address the issue of special interest because the question was absorbed by the existence of a community interest. The Court's approach is particularly peculiar if compared to that adopted, three years later, by the UNCLOS Arbitral Tribunal in relation to the Dutch standing against Russia in the Arctic Sunrise case, where the Tribunal held that the existence of a special interest - rectius, the possibility to characterise the Netherlands as injured state - rendered it moot an enquire on the existence of a standing based on the indirectly injured character of the Netherlands. ${ }^{130}$

Different observers took various views in relation to the ICJ's decision in the Belgium $v$. Senegal case to avoid the issue of special interest. Two authors have argued that the "decision to base admissibility on Belgium's alternative, erga omnes theory of jurisdiction rather than its claim to be an 'injured State' is, in all likelihood, borne from necessity rather than a desire by the ICJ to develop international law in this area", in order to overcome some judges' scepticism in the characterisation of Belgium as an injured state. ${ }^{131}$ Another commentator argued that the ICJ straightforwardly aimed at unifying the legal position of indirectly and directly injured states in relation to standing. ${ }^{132}$ Following this suggestion, in cases of violations of obligations erga omnes partes, all the states parties to the relevant convention have standing because of the mere fact of being contracting states, ${ }^{133}$ irrespective of any special interest.

Although this appears to be the conclusion of the Court in The Gambia v. Myanmar order, it would be appropriate that the Court, in the merits phase, addresses this point with more accuracy. This is particularly needed since the Gambia cannot claim any special interest, whereas the Belgium could and did on the basis of the nationality of some victims and the request for extradition. Accordingly, since the two situations are not equal, simply referring to the Belgium v. Senegal precedent, without addressing the legal implications -

\footnotetext{
130 The Arctic Sunrise Arbitration, supra note 103, para. 186. The opposite approach on the order of addressing the two arguments is noted by Treves, supra note 10, p. 274, note 705.

131 Mads Andenas and Thomas Weatherall, "International Court of Justice: Questions Relating to the Obligation to Extradite or Prosecute (Belgium v. Senegal) Judgment of 20 July 2012", 62 International \& Comparative Law Quarterly (2013) pp. 765-766.

132 Papa, supra note 50, pp. 1953-1954; Papa, supra note 110, pp. 747-748.

133 Huesa Vinaixa, supra note 110, p. 35.
} 
if any - of the factual differences, does not sound fully persuasive. This consideration, which was noted by Vice-President Xue in her separate opinion appended to the 2020 order, ${ }^{134}$ did not receive the attestation it deserved by the majority of the Court.

Finally, the ICJ should also address at the merits stage the issue whether, admitting the abstract legitimation of claims from indirectly injured states, these claims would be inadmissible if a directly injured state, which is specially affected by the violation, does exist. 135 This is the very position of Myanmar, as summarised by the Court in the 2020 order, according to which, The Gambia has a relevant legal interest, but this is not sufficient to sustain its standing since this interest is subsidiary to the interests of Bangladesh, allegedly the specially affected state. ${ }^{136}$ According to Myanmar, the consideration that a specially affected state exists bars the admissibility of a claim brought by an indirectly injured states, through a reasoning that alludes, without mentioning, the principle of indispensable party. ${ }^{137}$ As noted, this may imply that, in the view of Myanmar, a difference between the invocation of responsibility under Article 42 of DARS and under Article 48 of the DARS does exist, in the sense that priority should be given to claims from states that fall under the scope of Article $42 .{ }^{138}$

It is possible to question the soundness of the Myanmar's argument regarding the characterisation of Bangladesh as specially affected state, which is not based on any legal consideration apart from the assumption that the allegedly wrongful acts of Myanmar caused a flow of refugees to Bangladesh. ${ }^{139}$ This conclusion runs contrary to the wellestablished idea that, when serious violations are perpetrated by a state against its own population, there is no specially affected state because of the coincidence between the author of the wrongful act and the directly injured state. ${ }^{140}$ However, a more thorough explanation by the ICJ regarding the necessity of a special interest and on the

\footnotetext{
134 The Gambia v. Myanmar, supra note 5, Separate opinion of Vice-President Xue, paras. 4-5. Judge Xue opposed the conclusion of the majority regarding the standing of Belgium in Belgium v. Senegal, supra note 8, Dissenting opinion of Judge Xue, paras. 17-18.

135 Papa, supra note 110, pp. 750-751.

136 The Gambia v. Myanmar, supra note 5, para. 39. Myanmar arguments on the point can be found ibid., Verbatim Record, 11 December 2019, Remarks by C. Staker, paras. 55-56, 66.

137 Huesa Vinaixa, supra note 110, p. 39.

138 Ibid., p. 32.

139 The Gambia v. Myanmar, Verbatim Record, 11 December 2019, Remarks by C. Staker, para. 56. Myanmar did not offer any significant reasoning to sustain this characterisation. For some critical remarks, see Huesa Vinaixa, supra note $110,37-38$.

140 See Gaja, supra note 50, 115; Paolo Picone, "Le reazioni collettive ad un illecito erga omnes in assenza di uno stato individualmente leso", 96 Rivista di Diritto Internazionale (2013) p. $5 \mathrm{ff}$.
} 
coordination between reactions of specially affected states and indirectly injured ones ${ }^{141}$ would help solve these legal conundrums. The mere reference to the Belgium v. Senegal precedent is not enough, and, hopefully, the Court will take the opportunity to clarify the law at the merits stage.

\subsection{The Relationship between the ICJ's Case Law and the ILC's Codification}

A final point that deserves some attention is the dialogue - or the absence of dialogue between the ICJ and the ILC in relation to the issue of standing. Due to space constrains, the analysis is here limited to some few remarks.

The authority of the ILC in codifying and progressively developing customary international law, with particular reference to the law of state responsibility, is undisputable, 142 and the ICJ has largely endorsed the conclusions of the Commission, even before the 2001 finalisation of the DARS. ${ }^{143}$ Most of the commentaries on the interplay between the two institutions emphasise that there is a significant personal continuity between members of the Commission and members of the Court, which strengthen a mutual exercise of legitimisation through constant reciprocal references of the works of the other institution as authoritative expressions of customary international law. ${ }^{144}$

In light of this general understanding, it is striking that the ICJ has not referred to Article 42 or to Article 48 of the DARS in deciding the standing of Belgium and The Gambia in the Belgium v. Senegal case and in The Gambia v. Myanmar order. Although the former ILC's Special Rapporteur (and now Judge) Crawford's assurance that Belgium v. Senegal is

\footnotetext{
141 This complex topic has been rarely explored. Compare the views of Hugh Thirlway, "Injured and NonInjured States before the International Court of Justice", in Ragazzi, supra note 74, pp. 317-318, and Francesco Salerno, Diritto internazionale: principi e norme (4th ed., 2017) p. 505. See, more generally, Paolo Picone, "Il ruolo dello stato leso nelle reazioni collettive alle violazioni degli obblighi erga omnes", 95 Rivista di Diritto Internazionale (2012), p. $957 \mathrm{ff}$.

142 David Caron, "The ILC Articles on State Responsibility: The Paradoxical Relationship between Form and Authority", 96 American Journal of International Law (2002) p. 857ff.

${ }^{143}$ See, generally, Stephen M. Schwebel, "The Interactive Influence of the International Court of Justice and the International Law Commission", in Calixto A. Armas Barea et al. (eds), Liber Amicorum 'In Memoriam' of Judge José Maria Ruda (2000) p. 479ff.

${ }^{144}$ See the critical remarks of Antonio Cassese, "The Nicaragua and Tadić Tests Revisited in Light of the ICJ Judgment on Genocide in Bosnia", 18 European Journal of International Law (2007) p. 651; Andrea Bianchi, "Il tempio e i suoi sacerdoti. Considerazioni su retorica e diritto a margine del caso Germania c. Italia", 6 Diritti umani e diritto internazionale (2012) pp. 301-302.
} 
in line with Article $48,{ }^{145}$ the Court's silence is particularly surprisingly considering the numerous invocations and discussions of both provisions by the states involved in the litigation of community interests. ${ }^{146}$ The ICJ's attitude contrasts starkly with that of the ITLOS, which expressly linked the standing of indirectly injured states to litigate community interests to Article 48 of the DARS. ${ }^{147}$ Only in some individual opinions did the ICJ's Judges articulate their views on standing by reference to the DARS. ${ }^{148}$

The cautious approach of the Court may imply a divergence of opinions between the Court and the Commission, a lack of a shared view between the members of the Court, or something else completely. ${ }^{149}$ In any case, it is a source of confusion and the decision not to rely on the DARS forces the Court to present its arguments in a vague manner. Had the Court emphasised in the Belgium v. Senegal decision the relevance of Article 42 of the DARS, we would have understood that the Court considers a special interest to be necessary. Had the Court mentioned Article 48 of the DARS, we would have concluded that no special interest is required to bring a claim. Furthermore, whichever provision the Court referred to - either Article 42 or Article 48 - we have led to the assumption that the standing of special affected states or of indirectly injured states encompasses both obligations erga omnes and erga omnes partes, since the two provisions address both categories.

Rather, the Court is reluctant to endorse, on this specific issue, the work of the ILC. Accordingly, using the ILC's articles to interpret the silences of the Court may lead to reading too much in the Court's case law. At the same time, examining the Court's jurisprudence without considering the works of the ILC would be poor scholarship, since it is impossible to ignore the authoritativeness and impact of the DARS on judicial practice.

In light of these uncertainness, it would be beneficial if the Court would clarify the still vague contours of the standing of The Gambia in the merits phase of The Gambia v.

\footnotetext{
${ }^{145}$ Crawford, supra note 125, p. 204.

${ }^{146}$ See, e.g., Belgium v. Senegal, Memorial of the Kingdom of Belgium, 1 July 2010, para. 5.17; The Gambia v. Myanmar, Verbatim Record, 11 December 2019, The Gambia, Remarks by P. D'Argent, para. 9, note 210; ibid., Verbatim Record, 11 December 2019, Myanmar, Remarks by C. Staker, paras. 57, 63. See also, in the different context of UNCLOS arbitration, The Arctic Sunrise Arbitration, Memorial of the Kingdom of the Netherlands, supra note 101, para. 118.

${ }^{147}$ Responsibilities and Obligations of States, supra note 21, para. 180.

148 See, e.g., Belgium v. Senegal, supra note 8, Dissenting opinion of Judge Xue, para. 17; ibid., Separate opinion of Judge Skotnikov, para. 21.

${ }^{149}$ For some observations, see Papa, supra note 110, pp. 749-750.
} 
Myanmar, to shed some light on customary international law of standing, in general, and on the role of the DARS in particular.

\section{Conclusions}

Recognising standing of indirectly injured states for violations of obligations erga omnes and erga omnes partes is an important step towards increased state accountability. This is particularly relevant in light of the subject matter of similar disputes, which focus on the respect of fundamental rules protecting individual rights against oppression and mass atrocities.

When Article 48 of the DARS was discussed, some states raised the point that it would have been used to flood the Court with politically motivated litigations. ${ }^{150}$ To avoid this result, one observer suggested that the ICJ should maintain the possibility to assess whether the interest at stake is, case-by-case, important enough for the international community to allow an indirectly injured state to bring the claim notwithstanding the absence of a special interest. ${ }^{151}$ Notwithstanding these concerns, the ICJ is today far than blocked by an enormous backlog of litigations of community interests. Rather, after the pivotal 2012 Belgium v. Senegaljudgment, only two similar cases have been filed (Australia v. Japan and The Gambia v. Myanmar). Accordingly, it is possible to consider that the political implications ${ }^{152}$ and the costs ${ }^{153}$ of an application against another state before the ICJ are sufficient to avoid unnecessary litigations.

Moreover, as the litigation of community interests is subject to the usual rules on jurisdiction, similarly, any application must satisfy the condition of the existence of a legal dispute between the parties. Although it is not possible to investigate this aspect in detail here, suffice it to say that, indirectly injured states must demonstrates the existence of a dispute pursuant to the usual rules of the ICJ Statute. ${ }^{154}$ Claims in relation to a violation

\footnotetext{
150 See James Crawford, "Third Report on State Responsibility", YILC, (2000/II) (1), pp. 27-28 (regarding the concerns of Italy, Venezuela, Austria, and the United States; James Crawford, Fourth Report on State Responsibility, YILC, (2001/II) (1), p. 11 (with reference to Japan and France).

151 Tullio Treves, "The Settlement of Disputes and Non-Compliance Procedures", in Tullio Treves et al. (eds.), Non-Compliance Procedures and the Effectiveness of International Environmental Agreements (2009) p. 515. 152 See Gaja, supra note 50, p. 45.

153 See Alicia Miron, "Le coût de la justice internationale: enquête sur les aspects financiers du contentieux interétatique", 60 Annuaire français de droit international (2014) p. $241 \mathrm{ff}$.

${ }^{154}$ On the existence of a dispute, see, generally and for further references, Béatrice I. Bonafé, "Establishing the Existence of a Dispute before the International Court of Justice: Drawbacks and Implications", QIL,
} 
of an obligation erga omnes / erga omnes partes, if without a serious basis, risk being dismissed for lack of a real dispute. ${ }^{155}$ Accordingly, the usual rules on the existence of the ICJ's jurisdiction and on its exercise seem to be a further barrier against an avalanche of ill-founded cases.

Overall, after some initial hesitations, the case law of the ICJ has demonstrated an increased reliance on community interests and confidence that indirectly injured states may bring claims before the Court in response to violations. This trend could be consolidated at the merits stage of The Gambia v. Myanmar, which will offer the Court the opportunity to clarify some doubts over the legal challenges related to the litigation of community interests. Thus, the future decision on this case may contribute to the "further accumulation of case law [which] is needed"156 to corroborate and clarify the extant case law on litigation of community interests by indirectly injured states.

Zoom-out 45 (2017), p. 3ff.; Paolo Palchetti, "Dispute", in Max Planck Encyclopedia of International Procedural Law online (2018).

155 In relation to the litigation of community interests in The Gambia v. Myanmar order, see, e.g., Espaliú Berdud, supra note 110, pp. 53-56; Huesa Vinaixa, supra note 110, pp. 13-21. Compare with the isolated view of Judge Morelli, who considered that the existence of a dispute is the only relevant test (South West Africa Cases, Preliminary Objections, supra note 64, Dissenting Opinion of Judge Morelli, p. 564ff.; South West Africa, Second Phase, supra note 66, Separate Opinion of Judge Morelli, p. 59ff.).

${ }^{156}$ Tanaka, supra note 4, 321. 